\section{FIRST REPORT OF SEA LAVENDER IN SASK.}

by Dorothy R. and

Douglas E. Wade, Regina

On August 7, 1960, we stopped at an abandoned house which represents the entire town of Big Muddy, south of the Big Muddy Valley. Later we learned from a local rancher that the house once served as headquarters for the R.C.M.P. Exploring the hills and coulees in the vicinity of the town we came across a picturesque cemetery located on a hillside high above the valley floor. Prominent among those buried here were the Marshall family, who came into the valley in 1895 .

The cemetery was fenced and did not show the signs of heavy grazing which were evident in the surrounding grasslands. Through the cemetery and along the fence there was an unusual plant which reminded me of statice, the cultivated plant which is often used in dried form in floral arrangements.

Parts of the plant were pressed and it has been tentatively identified by Dr. George Ledingham, University of Saskatchewan, Regina Campus, as sea lavender, Limonium sp. Gray's Manual of Botany, 1950, mentions only two species for eastern North America and the genus Limonium, is not mentioned in floras of Manitoba, Alberta, or North Dakota. Limonium, of the family Plumbaginaceae, is made up of about 180 species, mostly perennial herbs, well scattered about the world but mainly growing on sea coasts in the northern hemisphere, especially in Asia. The Standard Cyclopedia of Horticulture, by L. H. Bailey, 1935, lists 32 species which may be cultivated.

Since this genus, Limonium, has apparently not been reported previously as being established in any of the prairie provinces or adjoining states it is interesting to think of this plant thriving in an abandoned cemetery which apparently has not been visited for many years.

It is interesting to speculate about how this plant came to this lonely ranch country. Was it first grown in a nearby garden and then deliberately seeded or planted in the cemetery?

\section{COMMON MULLEIN IN SASKATCHEWAN IN 1956}

by Mrs. MacGillivray, Moose Jaw

John Hudson's description of the Common Mullein, Verbascum thapsus L., in the March 1962 Blue Jay sounded very familiar and I looked through my pressed plants to get the details.

On July 31, 1956, I found a single plant along the Canadian National Railway track, near my home. Since I had not seen the plant previously in Saskatchewan I pressed leaves and flowers which I identified as Common Mullein. I have now sent this specimen to Dr. George Ledingham, University of Saskatchewan, Regina Campus, and he has verified the identification and deposited the specimen in the herbarium there.

It is interesting to note that this Moose Jaw specimen was not in the large waste railway area in the center of Moose Jaw but along the high dry bank of the C.N.R. where it skirts the northern fringe of the city. It will be interesting to see if this plant can become established and act as a weed in Saskatchewan.

\section{(Continued from page 83 )}

the parasite on the host plant. A thorough knowledge of the life-history of the parasite and its relationship with the host plant will probably give some clue. which can be exploited to control the spread of this pernicious parasite and conserve the natural wealth of our coniferous forests.

We are grateful to Mr. Norman Ferrier for assistance with photographic work.

\section{REFERENCES}

Kuijt, Job. 1955. Dwarf Mistletoes. Bot. Rev., 21:569-619.

1960. Morphological aspects of parasitism in the dwart mistletoe (Arceuthobium)., Univ. California Publ. Bot. 30:337-436.

Srivastava, L. M. and Esau, K. 1961. Relation of dwart mistletoe (Arceuthobium) to the xylem tissue of conifers. II. Effect of the parasite on the xylem anatomy of the host. Amer. J. Bot., 48:209-215.

Thoday. D. and Johnson, E. T. 1930. On Arceuthobium pusillum Peck. I. The Endophytic system. Ann. Bot., 44:393-413. 